\title{
Synergistic action of Viteselen with anti-Fasciola drug as a tool for improving fertility and hemato- biochemical biomarkers in Fasciola infected Sheep
}

Ghada H. Abdel-Rahman

Agricultural Research Center

Shimaa Abdel-Radi ( $\square$ shimaa.abdelradi@cu.edu.eg)

Cairo University Faculty of Veterinary Medicine https://orcid.org/0000-0001-7856-8147

\section{Research Article}

Keywords: Sheep, Fasciola, Antioxidant, Triclabendazol. Hematological, biochemical parameters

Posted Date: March 13th, 2021

DOl: https://doi.org/10.21203/rs.3.rs-307720/v1

License: (c) (1) This work is licensed under a Creative Commons Attribution 4.0 International License.

Read Full License

Version of Record: A version of this preprint was published at Journal of Parasitic Diseases on July 30th, 2021. See the published version at https://doi.org/10.1007/s12639-021-01423-9. 


\section{Abstract}

Fascioliasis causes public health problems and economic losses all over the world. The present study aimed to evaluate the synergistic action between Viteselen (anti-oxidant) and specific anti-Fasciola drug (Triclalbendazole (TCBZ) for improvement body condition of $F$. gigantica naturally infected sheep with reference to some hematological and biochemical biomarkers in their sera. Animals were divided into five equal groups include G-1 as control non-infected animals, G-2 to G-5 are Fasciola naturally infected animals. G-2 is non-treated group, animals in G-3 were treated with TCBZ, animals in G-4 were injected by Viteselen and those in G-5 were treated by both TCBZ and Viteselen. The results revealed significant decrease in mean eggs in feces and $F$. gigantica circulating antigens (FCAg) in sera of TCBZ treated sheep after the 1st week post treatment. Complete disappearance of eggs from feces of drug treated groups was recorded at 21 st d.p.t. While the value of FCAg decreased to negative at 14 th d.p.t. The highest significant improvement $(\mathrm{p}<0.05)$ in the estimated hematological parameters $(\mathrm{RBCs}, \mathrm{Hb}$ and TLC), liver enzymes (AST and ALT), oxidative stress and antioxidant markers (TAC, MDA, SOD and GSH) and reproductive hormones (Progesterone and Estradiol) was recorded in animals in G-5 followed by G-3. While non-significant improvement was recorded in animals in G-4 in comparison with those in the control group. This improvement increased with increasing the time post treatment.

For conclusion; using of Viteselen in association with specific anti-parasitic drug improved the general health parameters and reproductive performance of the investigated sheep.

\section{Introduction}

Fascioliasis is a parasitic disease caused by the digenetic trematode Fasciola species which causes public health problems and decrease productivity of the infected ruminants in different regions of the world (Rinaldi et al. 2015). This liver fluke may cause weakness and decrease in fertility due to alternation of normal metabolism and balance of sex hormones (Kaplan 2001). Moreover, the toxic and mechanical effects of Fasciola spp lead to bad effect on the liver tissue and increase the level of hepatic enzymes such as alanine aminotransferase (ALT) and aspartate aminotransferase (AST) which are useful for diagnosing of hepatobiliary diseases (Shrimali et al. 2016). Measuring serum biochemical and oxidative stress parameters could be useful in early diagnosis and prognosis of fascioliasis in sheep and could be used to observe the progress of infection as a sensitive diagnostic tool for field infection (Hodzic et al. 2013 and Bahrami et al. 2014). A number of flukicide drugs were used in sheep including the triclabendazole (TCBZ) which demonstrated high efficacy against both adult and immature flukes at early days post-infection unlike the other flukicides but excessive dependence on anti-parasitic drugs may cause resistance (Kelley et al. 2016). Antioxidants, vitamins and trace minerals enhance immunity of the animal and improve its productivity and their deficiency may affect ROS production which are essential factors of cell division, differentiation and growth (Kafilzadeh et al. 2014). Combinations of antioxidants and flukicides drugs may be more effective than applying larger quantities of one of these products (Young and Lowe 2001). 
From all the previous background data and aiming to maximize the benefits from eradication of infection using traditional drugs, the present study aimed to evaluate the synergistic or antagonistic effect of using Viteselen (as anti-oxidant) with TCBZ (as specific anti-Fasciola drugs) on effective eradication of Fasciola and improvement the body condition and productivity of sheep which are naturally infected with this parasite with reference to some hematological, biochemical and oxidative stress parameters in sera.

\section{Materials And Methods}

\section{Animals selected for the study}

Twenty five non-pregnant ewes of $1.5-2$ years old and about $30-35 \mathrm{~kg}$ body weight were identified by ear tags and kept in separate groups along the period of the study. The ewes received the same healthy balanced feeding, drinking and hygienic housing condition along the study period. Moreover, they were subjected to gynecological examination via rectal palpation and using ultra sonic examination to detect the ovarian and genital tract condition. These ewes were allocated into five equal groups; each group contains five animals as the following; (G-1), as control non-infected animals, Then 4 groups (from $\mathrm{G}-2$ to G-5) contained Fasciola naturally infected animals. Animals in (G-2) were kept without treatment till the end of experiment (day 60 ). While those in (G-3) were treated with Triclabendazole (TCBZ) only. Moreover, animals in (G-4) injected by the anti-oxidant (Viteselen) only and those in (G-5) were treated by (TCBZ) one time and weekly injected with Viteselen along the experiment period (60 day).

\section{Collection and preparation of samples}

\section{a) Fecal samples}

Fecal samples were freshly collected from the rectum of each ewe before the beginning of the trial and at weakly intervals during the first 3 weeks $\left(0,7^{\text {th }}, 14^{\text {th }}\right.$, and $21^{\text {st }}$ day) then at day $40^{\text {th }}$ and $60^{\text {th }}$ post treatment (P.T) (end of the trial). Parasitological examination was performed using Fluke finder technique according to Welch et al. (1987) and the concentration flotation technique; number of different parasites eggs/gram feces was determined by using McMaster technique as demonstrated by Soulsby (1982)

\section{b) Blood samples}

Jugular blood samples were collected with or without dipotassium salt of ethylene diamine tetra- acetic acid (EDTA) anticoagulant in clean centrifuge tubes at weakly intervals during the first 3 weeks $\left(0,7^{\text {th }}\right.$, $14^{\text {th }}$, and $21^{\text {st }}$ day) then at day $40^{\text {th }}$ and $60^{\text {th }}$ P.T. The uncoagulated blood samples were used for evaluating the target clinical parameters while serum was separated from the other clotted blood samples after centrifugation at $3000 \mathrm{rpm}$ for 10 minutes then the clear non-hemolized supernatant sera were kept at $-20^{\circ} \mathrm{C}$ till used for estimation the biochemical parameters and oxidative stress and antioxidant markers. Also these sera were used for the serological studies.

\section{Chemicalsand drugs used}




\section{a) FASINEX @ $10 \% \mathrm{w} / \mathrm{v}$}

Triclabendazole 10\% (TCBZ) oral suspension drench for sheep $(10 \mathrm{mg} / \mathrm{kg}$ ) according to the direction of Producer Company (NOVARTIS).

\section{b) Viteselen $₫$}

Viteselen was administrated by intramuscular route, at a dose level of $20 \mathrm{ml} / \mathrm{head}$, once/week along the period of the experiment ( 60 days). Each $1 \mathrm{ml}$ of the Viteselen contains $1.67 \mathrm{mg}$ sodium selenite and 150 mg of Vit. E (the Egyptian Co. for Chemicals and pharmaceuticals).

\section{Hematological studies}

According to Feldman et al. (2000) calculation of total leukocytic count (TLC) and erythrocytic cell counts (RBCs) were performed using an improved Neubauer hemocytometer. Moreover, hemoglobin $(\mathrm{Hb})$ concentration was determined calorimetrically using the cyanmethemoglobin method.

\section{Biochemical assay}

The prepared serum samples were used for biochemical analysis of total antioxidant capacity (TAC) which was measured according to Cortassa et al. (2004), serum lipid peroxide (Malon dialdehyde) MDA according to the method demonstrated by Placer et al. (1966), superoxide dismutase (SOD) activity that was determined according to Rai et al. (2006). Also reduced glutathione (GSH), serum transaminases including aspartate amino transaminase (AST) and alanine amino transaminase (ALT) were measured according to Kaneko et al. (2009). Moreover, Progesterone and Estradiol hormones were assayed by direct enzyme linked immunoassay (ELISA) according to Munro et al. (1991).

\section{Sandwich ELISA for diagnosis of circulating Fasciola antigen}

\section{a) Preparation of gigantica excretory secretory antigen (ES Ag)}

F. gigantica ES Ag was prepared from flukes collected from condemn liver of naturally infected freshly slaughtered sheep according to Marrero et al. (1988). The clean active worms were incubated (4 worms/ $10 \mathrm{ml})$ in PBS $(7.4 \mathrm{pH})$ for $3 \mathrm{~h}$. at $37^{\circ} \mathrm{C}$. The worms were removed and the fluid was collected then centrifugation at $6000 \mathrm{rpm}$ at $4{ }^{\circ} \mathrm{C}$ for $1 \mathrm{~h}$. After that, this fluid was concentrated by dehydration versus polyethyleneglycol in molecular porous membrane tubing 6-8 MW cut off (Spectrum Medical Inc., Los Angeles, CA 900060) according to Mahdy et al. (2017) and its protein content was measured by the method of Bradford (1976) then allocated into $1 \mathrm{ml}$ vial then stored at $-20^{\circ} \mathrm{C}$ until use.

\section{b) Reference hyper-immune sera}

Rabbit and rat hyper-immune sera (HIS) as positive reference sera were prepared against $F$. gigantica ES Ag according to Langley and Hillyer (1989). Two month-old white New Zealand rabbits and three $120 \mathrm{gm}$ albino laboratory breed rats were injected by 100 ug and 50 ug protein / injection, respectively. The initial 
injection was S/C in mineral oil as adjuvant. At 1:1/ volume then injected one time S/C in different places in the back of the animals. After 3 weeks another $1.2 \mathrm{mg}$ of protein was mixed again and divided into 3 doses, then injected I/M at two weeks intervals. Rabbits and rats were bled from the ear and tail vein for blood collection and serum separations two weeks after the last injection. The collected sera were stored at $-20^{\circ} \mathrm{C}$ until used in the sandwich ELISA.

\section{c) Procedures of Sandwich ELISA (Antigen Capture Assay)}

F. gigantica circulating antigen in sera of the investigated ewes was detected using two antibodies sandwich ELISA, according to Attallah et al. (1999). After checkerboard titrations the test condition was primary determined. ELISA plates were coated with $50 \mu \mathrm{l} /$ well of 1:100 Rabbit HIS diluted in carbonate buffer ( $\mathrm{pH}$ 9.6) then incubated overnight at $4^{\circ} \mathrm{C}$. After washing, two replicate of tested sheep serum (1:50) samples were added, then incubated for 3 hours at $37^{\circ} \mathrm{C}$. After washing, $50 \mu \mathrm{L} /$ well of the prepared rat HIS was added then incubated as before. After washing, $50 \mu \mathrm{L}$ of HRPC sheep anti-rat IgG ((Sigma,USA) , diluted 1:1000 with in PBS, was added then incubated for 1 hour. After washing, $50 \mu$ of the Ortho-phenylenediamidine (OPD) was added at $340 \mu \mathrm{g} / \mathrm{ml}$ substrate buffer. The reaction was proceeding for 15 minutes, then it was terminated using $0.2 \mathrm{M} \mathrm{H}_{2} \mathrm{SO}_{4}$. The absorbance values was read using an automated Titertek multiscan plate reader (Titertek-Berthold, Berthold Detection Systems GmbH, Pforzheim, Germany), at $450 \mathrm{~nm}$. The cut-off value was established based on the mean optical density (OD) of negative control sera plus 2 standard deviations.

\section{Statistical analysis}

The data obtained in the present study were subjected to statistical analysis of variance (ANOVA). The obtained data were expressed as mean standard deviation $( \pm S D)$. Values of $p \leq 0.05$ were considered to be statistically significant. Statistical analysis were performed using SPSS version 26 software (SPSS Inc, Chicago, IL, USA).

\section{Results}

The level of Fasciola infection in all investigated ewes was determined at the beginning of infection via estimation of $F$. gigantica eggs (eggs per gram; e.p.g) in feces. Animals were selected to represent equally infected groups according to mean (e.p.g) as described in table (1). It was found that animals in each group were infected by 2-5 e,p.g in their feces. The level of Fasciola circulating antigen (FCAg) in sera of these animals was ranged from $0.703 \pm 0.17$ to $0.766 \pm 0.24$ at the zero day of the experiment using ELISA. Following up the variation in mean e.p.g in their feces and the value of FCAg in their sera was demonstrated during the first four weeks of the experiment (Table 1). It was noticed that the level of infection by eggs in feces and by FCAg sera of animals in G-2 and G-4 still present without changes till the day 21 st of the experiment, without significant difference in their values between this two groups. While the mean number of e.p.g and FCAg decreased after the 1st week post treatment by TCBZ in G-3 as well as in G-5 that treated by combinations of TCBZ and Viteselen. Complete disappearance of eggs from 
feces of G-3 and G-5 treated ewes was recorded at 21st d.p.t., Moreover; the value of FCAg was decreased to negative at the 14th d.p.t in both groups.

Table 1

Estimation of F. gigantica eggs in feces and circulating Ag in sera of the investigated sheep groups during the study period (mean $\pm \mathrm{SD}$ ).

\begin{tabular}{|c|c|c|c|c|c|}
\hline \multirow[t]{2}{*}{ Sheep groups } & \multirow[t]{2}{*}{ Tested values } & \multicolumn{4}{|c|}{ Observation period } \\
\hline & & zero d.b.t. & 7th d.p.t. & 14th d.p.t. & 21 st d.p.t. \\
\hline \multirow{3}{*}{$\begin{array}{l}\text { G-1 } \\
\text { (Healthy non infected) }\end{array}$} & $\begin{array}{l}\text { No. still shed } \\
\text { eggs }\end{array}$ & 0.0 & 0.0 & 0.0 & 0.0 \\
\hline & Mean e.p.g & 0.0 & 0.0 & 0.0 & 0.0 \\
\hline & Mean ELISA OD & $\begin{array}{l}0.031 \pm \\
0.11\end{array}$ & $\begin{array}{l}0.028 \pm \\
0.13\end{array}$ & $\begin{array}{l}0.030 \pm \\
0.21\end{array}$ & $\begin{array}{l}0.033 \pm \\
0.16\end{array}$ \\
\hline \multirow{3}{*}{$\begin{array}{l}\text { G-2 } \\
\text { (infected non-treated) }\end{array}$} & $\begin{array}{l}\text { No. still shed } \\
\text { eggs }\end{array}$ & $5 / 5$ & $5 / 5$ & $5 / 5$ & $5 / 5$ \\
\hline & Mean e.p.g & $2-5(3.6)$ & $2-5(3.2)$ & $2-5(3.4)$ & $2-5(3.4)$ \\
\hline & Mean ELISA OD & $\begin{array}{l}0.722 \pm \\
0.20\end{array}$ & $\begin{array}{l}0.731 \pm \\
0.11\end{array}$ & $\begin{array}{l}0.755 \pm \\
0.24\end{array}$ & $\begin{array}{l}0.776 \pm \\
0.19\end{array}$ \\
\hline \multirow{3}{*}{$\begin{array}{l}\text { G-3 } \\
\text { (Treated by TCBZ only) }\end{array}$} & $\begin{array}{l}\text { No. still shed } \\
\text { eggs }\end{array}$ & $5 / 5$ & $3 / 5$ & $2 / 5$ & $0 / 5$ \\
\hline & Mean e.p.g & $2-4(3.2)$ & $1-3(1.6)$ & $1-2(1.2)$ & 0.0 \\
\hline & Mean ELISA OD & $\begin{array}{l}0.715 \pm \\
0.18\end{array}$ & $\begin{array}{l}0.532 \pm \\
0.21\end{array}$ & $\begin{array}{l}0.066 \pm \\
0.12\end{array}$ & $\begin{array}{l}0.036 \pm \\
0.25\end{array}$ \\
\hline \multirow{3}{*}{$\begin{array}{l}\text { G-4 } \\
\text { (supplemented by } \\
\text { Viteselen ) }\end{array}$} & $\begin{array}{l}\text { No. still shed } \\
\text { eggs }\end{array}$ & $5 / 5$ & $5 / 5$ & $5 / 5$ & $5 / 5$ \\
\hline & Mean e.p.g & $2-4(3.2)$ & $2-5(3.4)$ & $2-5(3.4)$ & $2-5(3.6)$ \\
\hline & Mean ELISA OD & $\begin{array}{l}0.655 \pm \\
0.21\end{array}$ & $\begin{array}{l}0.703 \pm \\
0.17\end{array}$ & $\begin{array}{l}0.709 \pm \\
0.24\end{array}$ & $\begin{array}{l}0.728 \pm \\
0.15\end{array}$ \\
\hline \multirow{3}{*}{$\begin{array}{l}\text { G-5 } \\
\text { (TCBZ and Viteselen.) }\end{array}$} & $\begin{array}{l}\text { No. still shed } \\
\text { eggs }\end{array}$ & $5 / 5$ & $3 / 5$ & $2 / 5$ & $0 / 5$ \\
\hline & Mean e.p.g & $2-5(3.4)$ & $1-2(1.4)$ & $1 \& 2(0.6)$ & 0.0 \\
\hline & Mean ELISA OD & $\begin{array}{l}0.766 \pm \\
0.24\end{array}$ & $\begin{array}{l}0.511 \pm \\
0.13\end{array}$ & $\begin{array}{l}0.052 \pm \\
0.22\end{array}$ & $\begin{array}{l}0.033 \pm \\
0.20\end{array}$ \\
\hline
\end{tabular}

Concerning improvement in the investigated clinical parameters in different treated groups, a significant improvement $(p<0.05)$ was recorded in G-5 followed by those in $G-3$, non-significant improvement was 
recorded in animals of G-4, in comparison with infected non-treated animals in G-2. The level of improvement in animals in G-3 to G-5 increase with increasing in the time elapsed post treatment. The pattern of improvement was recorded in comparing with the changes in hematological parameters (RBCs, $\mathrm{Hb}$ and TLC) before and after treatment (Table 2). A slight non-significant improvement was recorded at 21 st d.p.t., while significant improvement was noticed at 60th d.p.t. The highest improvement was recorded in G-5, followed by G-3, while mild non-significant improvement was recorded in animals of G-4 at the end of the observation time (60th d.p.t.). 
Table 2

Hematological parameters of the investigated sheep groups through the study (mean \pm SD).

\begin{tabular}{|c|c|c|c|c|}
\hline \multirow[t]{2}{*}{ Observation period } & \multirow[t]{2}{*}{ Sheep groups } & \multicolumn{3}{|c|}{ Evaluated Parameters } \\
\hline & & $\operatorname{RBCs}\left(x 10^{6} / \mu \mathrm{L}\right)$ & $\mathrm{Hb}(\mathrm{g} / \mathrm{dl})$ & $\operatorname{TLC}\left(\mathrm{x} 10^{3} / \mu \mathrm{l}\right)$ \\
\hline \multirow[t]{5}{*}{0 d.b.t. } & G -1 & $9.70 \pm 0.10^{\mathrm{a}}$ & $11.53 \pm 0.11^{\mathrm{a}}$ & $8.85 \pm 0.01^{a}$ \\
\hline & G -2 & $7.10 \pm 0.30^{\mathrm{b}}$ & $8.30 \pm 0.04^{b}$ & $15.56 \pm 0.60^{\mathrm{b}}$ \\
\hline & $G-3$ & $7.50 \pm 0.20^{b}$ & $8.17 \pm 0.30^{b}$ & $14.70 \pm 0.20^{b}$ \\
\hline & $G-4$ & $6.99 \pm 0.70^{b}$ & $7.99 \pm 0.34^{b}$ & $13.93 \pm 0.21^{b}$ \\
\hline & $G-5$ & $7.40 \pm 0.60^{b}$ & $8.37 \pm 0.22^{b}$ & $15.56 \pm 0.04^{b}$ \\
\hline \multirow[t]{5}{*}{ 21st d.p.t. } & G -1 & $9.95 \pm 0.11^{\mathrm{a}}$ & $11.51 \pm 0.31^{\mathrm{a}}$ & $8.88 \pm 0.02^{a}$ \\
\hline & G -2 & $7.10 \pm 0.11^{b}$ & $6.11 \pm 0.31^{b}$ & $15.31 \pm 0.31^{b}$ \\
\hline & $G-3$ & $7.93 \pm 0.18^{b}$ & $7.16 \pm 0.13^{b}$ & $12.73 \pm 0.20^{b}$ \\
\hline & $G-4$ & $7.40 \pm 0.20^{b}$ & $7.47 \pm 0.30^{b}$ & $13.18 \pm 0.20^{b}$ \\
\hline & $G-5$ & $7.70 \pm 0.10^{b}$ & $7.83 \pm 0.11^{b}$ & $11.10 \pm 0.01^{b}$ \\
\hline \multirow[t]{5}{*}{ 40th d.p.t. } & G -1 & $9.75 \pm 0.12^{\mathrm{a}}$ & $11.56 \pm 0.10^{a}$ & $8.80 \pm 0.41^{a}$ \\
\hline & G -2 & $7.40 \pm 0.14^{b}$ & $6.61 \pm 0.36^{b}$ & $14.26 \pm 0.34^{b}$ \\
\hline & $G-3$ & $8.04 \pm 0.18^{b}$ & $8.56 \pm 0.13^{b}$ & $10.73 \pm 0.20^{\mathrm{b}}$ \\
\hline & $G-4$ & $8.01 \pm 0.12^{b}$ & $8.16 \pm 0.10^{b}$ & $11.60 \pm 0.41^{b}$ \\
\hline & $G-5$ & $9.40 \pm 0.60^{\mathrm{a}}$ & $11.37 \pm 0.22^{a}$ & $8.96 \pm 0.04^{a}$ \\
\hline \multirow[t]{5}{*}{ 60th d.p.t. } & G -1 & $9.38 \pm 0.14^{\mathrm{a}}$ & $11.55 \pm 0.13^{a}$ & $8.81 \pm 0.31^{a}$ \\
\hline & G -2 & $7.10 \pm 0.14^{b}$ & $6.11 \pm 0.36^{b}$ & $15.66 \pm 0.34^{b}$ \\
\hline & $G-3$ & $8.08 \pm 0.14^{b}$ & $8.19 \pm 0.36^{b}$ & $09.76 \pm 0.34^{b}$ \\
\hline & $G-4$ & $8.03 \pm 0.18^{b}$ & $8.66 \pm 0.13^{b}$ & $10.53 \pm 0.20^{b}$ \\
\hline & $G-5$ & $9.60 \pm 0.30^{\mathrm{a}}$ & $11.51 \pm 0.04^{\mathrm{a}}$ & $8.83 \pm 0.60^{a}$ \\
\hline
\end{tabular}


Table 3

Variations in values of liver enzymes of the investigated sheep groups through the study period (mean $\pm S D$ ).

\begin{tabular}{|c|c|c|c|}
\hline \multirow[t]{2}{*}{ Observation times } & \multirow[t]{2}{*}{ Sheep groups } & \multicolumn{2}{|c|}{ Evaluated Parameters } \\
\hline & & AST (U/L) & ALT (U/L) \\
\hline \multirow[t]{5}{*}{0 d.b.t. } & G -1 & $25.19 \pm 0.14^{a}$ & $15.06 \pm 0.24^{\mathrm{a}}$ \\
\hline & G -2 & $40.76 \pm 0.06^{b}$ & $38.18 \pm 0.16^{b}$ \\
\hline & $G-3$ & $35.99 \pm 0.05^{b}$ & $35.46 \pm 0.41^{b}$ \\
\hline & $G-4$ & $43.59 \pm 0.08^{b}$ & $36.46 \pm 0.65^{b}$ \\
\hline & $G-5$ & $39.59 \pm 0.06^{b}$ & $37.46 \pm 0.31^{b}$ \\
\hline \multirow[t]{5}{*}{ 21st d.p.t. } & $\mathrm{G}-1$ & $24.33 \pm 0.12^{a}$ & $15.15 \pm 0.22^{a}$ \\
\hline & $G-2$ & $39.76 \pm 0.06^{b}$ & $39.78 \pm 0.16^{b}$ \\
\hline & $G-3$ & $32.19 \pm 0.01^{b}$ & $35.47 \pm 0.35^{b}$ \\
\hline & $G-4$ & $36.59 \pm 0.08^{b}$ & $38.46 \pm 0.25^{b}$ \\
\hline & $G-5$ & $39.39 \pm 0.07^{b}$ & $32.46 \pm 0.14^{b}$ \\
\hline \multirow[t]{5}{*}{ 40th d.p.t. } & G -1 & $23.13 \pm 0.13^{a}$ & $15.04 \pm 0.15^{a}$ \\
\hline & $G-2$ & $49.97 \pm 0.08^{b}$ & $47.55 \pm 0.55^{b}$ \\
\hline & $G-3$ & $35.69 \pm 0.03^{c}$ & $33.59 \pm 0.08^{c}$ \\
\hline & $G-4$ & $39.99 \pm 0.05^{c}$ & $36.84 \pm 0.55^{c}$ \\
\hline & $G-5$ & $26.59 \pm 0.08^{a}$ & $14.46 \pm 0.21^{a}$ \\
\hline \multirow[t]{5}{*}{ 60th d.p.t. } & G -1 & $25.15 \pm 0.11^{a}$ & $15.14 \pm 0.11^{a}$ \\
\hline & $\mathrm{G}-2$ & $46.76 \pm 0.06^{b}$ & $44.38 \pm 0.13^{b}$ \\
\hline & $G-3$ & $31.65 \pm 0.15^{c}$ & $32.96 \pm 0.31^{c}$ \\
\hline & $G-4$ & $34.59 \pm 0.12^{c}$ & $30.56 \pm 0.25^{c}$ \\
\hline & $G-5$ & $25.18 \pm 0.03^{a}$ & $15.04 \pm 0.65^{a}$ \\
\hline
\end{tabular}


Table 4

Variations in oxidative stress and antioxidant biomarkers concentrations of the investigated sheep groups during the study period (mean $\pm \mathrm{SD}$ ).

\begin{tabular}{|c|c|c|c|c|c|}
\hline \multirow{2}{*}{$\begin{array}{l}\text { Observation } \\
\text { times }\end{array}$} & \multirow{2}{*}{$\begin{array}{l}\text { Sheep } \\
\text { groups }\end{array}$} & \multicolumn{4}{|c|}{ Evaluated Parameters } \\
\hline & & $\begin{array}{l}\text { TAC } \\
\text { (mmol/L) }\end{array}$ & $\begin{array}{l}\text { MDA } \\
(\mathrm{nmol} / \mathrm{ml})\end{array}$ & $\begin{array}{l}\text { SOD (SOD/ml } \\
\text { blood) }\end{array}$ & $\begin{array}{l}\text { GSH } \\
(\mathrm{U} / \mathrm{L})\end{array}$ \\
\hline \multirow[t]{5}{*}{0 d.b.t. } & G -1 & $\begin{array}{l}0.67 \pm 0.04 \\
a\end{array}$ & $10.96 \pm 0.07^{a}$ & $\begin{array}{l}258.21 \pm \\
2.09^{a}\end{array}$ & $11.25 \pm 0.11^{a}$ \\
\hline & G -2 & $0.23 \pm 0.13^{b}$ & $\begin{array}{l}24.26 \pm 0.24 \\
b\end{array}$ & $\begin{array}{l}140.44 \pm \\
1.10^{b}\end{array}$ & $7.01 \pm 0.34^{b}$ \\
\hline & $G-3$ & $0.21 \pm 0.06^{b}$ & $26.11 \pm 0.11$ & $\begin{array}{l}142.34 \pm \\
2.05^{\mathrm{b}}\end{array}$ & $8.01 \pm 0.14^{b}$ \\
\hline & $G-4$ & $0.23 \pm 0.08^{b}$ & $25.26 \pm 0.41$ & $\begin{array}{l}150.44 \pm \\
1.11^{\mathrm{b}}\end{array}$ & $7.09 \pm 0.24^{b}$ \\
\hline & $G-5$ & $0.22 \pm 0.03^{b}$ & $23.28 \pm 0.31$ & $\begin{array}{l}145.44 \pm \\
2.45^{b}\end{array}$ & $7.07 \pm 0.14^{b}$ \\
\hline \multirow[t]{5}{*}{ 21st d.p.t. } & G -1 & $\begin{array}{l}0.65 \pm 0.05 \\
a\end{array}$ & $10.86 \pm 0.06^{a}$ & $\begin{array}{l}251.21 \pm \\
1.89^{a}\end{array}$ & $12.21 \pm 0.13^{a}$ \\
\hline & G -2 & $0.25 \pm 0.11^{b}$ & $\begin{array}{l}32.26 \pm 0.21 \\
b\end{array}$ & $\begin{array}{l}133.53 \pm \\
1.13^{b}\end{array}$ & $6.01 \pm 0.14^{b}$ \\
\hline & $G-3$ & $\begin{array}{l}0.29 \pm 0.03 \\
b\end{array}$ & $\begin{array}{l}22.86 \pm 0.27 \\
b\end{array}$ & $\begin{array}{l}139.78 \pm \\
2.43^{b}\end{array}$ & $9.24 \pm 0.25^{\mathrm{b}}$ \\
\hline & $G-4$ & $0.30 \pm 0.07^{b}$ & $\begin{array}{l}23.57 \pm 0.12 \\
b\end{array}$ & $\begin{array}{l}135.75 \pm \\
3.53^{b}\end{array}$ & $8.28 \pm 0.18^{b}$ \\
\hline & $G-5$ & $\begin{array}{l}0.37 \pm 0.02 \\
b\end{array}$ & $26.41 \pm 0.11^{b}$ & $\begin{array}{l}137.68 \pm \\
1.53^{b}\end{array}$ & $9.24 \pm 0.15^{b}$ \\
\hline \multirow[t]{5}{*}{ 40th d.p.t. } & G -1 & $\begin{array}{l}0.69 \pm 0.09 \\
a\end{array}$ & $10.82 \pm 0.15^{\mathrm{a}}$ & $\begin{array}{l}255.21 \pm \\
1.89^{a}\end{array}$ & $11.27 \pm 0.12^{a}$ \\
\hline & G -2 & $0.28 \pm 0.08^{b}$ & $\begin{array}{l}31.26 \pm 0.21 \\
b\end{array}$ & $\begin{array}{l}120.58 \pm \\
2.28^{b}\end{array}$ & $8.08 \pm 0.28^{b}$ \\
\hline & $G-3$ & $0.57 \pm 0.03^{c}$ & $19.66 \pm 0.13^{c}$ & $\begin{array}{l}161.91 \pm \\
1.53^{c}\end{array}$ & $10.02 \pm 0.16^{c}$ \\
\hline & $G-4$ & $0.49 \pm 0.14^{c}$ & $28.86 \pm 0.07^{c}$ & $\begin{array}{l}158.68 \pm \\
1.58^{c}\end{array}$ & $9.28 \pm 0.13^{c}$ \\
\hline & $G-5$ & $0.68 \pm 0.01^{a}$ & $10.84 \pm 0.10^{a}$ & $\begin{array}{l}255.11 \pm \\
2.23^{\mathrm{a}}\end{array}$ & $11.24 \pm 0.11^{a}$ \\
\hline
\end{tabular}




\begin{tabular}{|c|c|c|c|c|c|}
\hline \multirow[t]{5}{*}{ 60th d.p.t. } & G -1 & $\begin{array}{l}0.65 \pm 0.07 \\
\text { a }\end{array}$ & $10.86 \pm 0.22^{a}$ & $\begin{array}{l}259.23 \pm \\
1.83^{\mathrm{a}}\end{array}$ & $13.03 \pm 0.14^{a}$ \\
\hline & G -2 & $0.29 \pm 0.06^{b}$ & $\begin{array}{l}34.26 \pm 0.14 \\
\mathrm{~b}\end{array}$ & $\begin{array}{l}110.54 \pm \\
1.25^{\mathrm{b}}\end{array}$ & $7.95 \pm 0.39^{b}$ \\
\hline & $G-3$ & $0.58 \pm 0.04^{c}$ & $27.95 \pm 0.26^{c}$ & $\begin{array}{l}167.78 \pm \\
2.03^{\mathrm{c}}\end{array}$ & $9.95 \pm 0.15^{c}$ \\
\hline & $G-4$ & $0.47 \pm 0.06^{c}$ & $29.86 \pm 0.17^{c}$ & $\begin{array}{l}159.65 \pm \\
1.53^{\mathrm{c}}\end{array}$ & $10.66 \pm 0.13^{c}$ \\
\hline & $G-5$ & $0.66 \pm 0.01^{\mathrm{a}}$ & $10.81 \pm 0.13^{a}$ & $\begin{array}{l}257.78 \pm \\
1.64^{\mathrm{a}}\end{array}$ & $11.23 \pm 0.17^{a}$ \\
\hline
\end{tabular}

At the 60th d.p.t., the synergistic action of addition of TCBZ and Viteselen revealed high improvement of the investigated parameters in $\mathrm{G}-5$ animals which revealed non-significant differences in comparison with the healthy control group (G-1) as the following; (RBCs, $9.60 \pm 0.30),(\mathrm{Hb}, 11.51 \pm 0.04)$ and (TLC, $8.83 \pm$ $0.60)$ respectively.

It was also noticed that the investigated liver enzymes (AST and ALT) showing the same pattern of improvement in comparison with the control non treated group (G-2). As the highest significant improvement was recorded at 60th d.p.t. especially in (G-5) which revealed non-significant differences in comparison with the healthy control group; (AST, $25.18 \pm 0.03$ ), and (ALT, $15.04 \pm 0.65$ ) respectively as described in table (3).

Following up the changes in the values of oxidative stress and antioxidant markers (TAC, MDA, SOD and GSH) in different treated groups in comparison with healthy control one (G-1), the data in table (4) showing that the highest significant improvement in these parameters was recorded at the 60th d.p.t. specially in G-5 treated by both of TCBZ and Viteselen. As there were non-significant differences in the improvement of the investigated parameters in G-5 in comparing with those of the healthy control group as the following; (TAC, $0.66 \pm 0.01)$, (MDA, $10.81 \pm 0.13)$, (SOD, $257.78 \pm 1.64)$ and (GSH, $11.23 \pm 0.17)$.

All of the previous improvement reflected also on the estimated reproductive hormones (Progesterone and Estradiol). The improving was directly related also with increasing in the time post treatment (Table 5). As previously recorded; there was a high significant improvement at 60th d.p.t. specially in animals of G-5 which revealed non-significant differences in comparison with the healthy control group as the following; $(P, 2.01 \pm 0.10)$ and $(E, 1.71 \pm 0.13)$ respectively. 
Table 5

Variations in some reproductive hormones concentrations in the investigated sheep groups during the study period (mean $\pm \mathrm{SD}$ ).

\begin{tabular}{|c|c|c|c|}
\hline \multirow[t]{2}{*}{ Observation times } & \multirow[t]{2}{*}{ Sheep groups } & \multicolumn{2}{|l|}{ Evaluated Parameters } \\
\hline & & Progesterone (ng/mL) & Estradiol (pg/ml) \\
\hline \multirow[t]{5}{*}{0 d.b.t. } & G -1 & $2.02 \pm 0.02^{a}$ & $1.72 \pm 0.19^{a}$ \\
\hline & G -2 & $0.56 \pm 0.07^{b}$ & $2.25 \pm 0.05^{b}$ \\
\hline & $G-3$ & $0.58 \pm 0.05^{b}$ & $2.28 \pm 0.01^{b}$ \\
\hline & $G-4$ & $0.55 \pm 0.06^{b}$ & $2.65 \pm 0.03^{b}$ \\
\hline & $G-5$ & $0.54 \pm 0.08^{b}$ & $2.35 \pm 0.05^{b}$ \\
\hline \multirow[t]{5}{*}{ 21st d.p.t. } & G -1 & $2.10 \pm 0.02^{a}$ & $1.73 \pm 0.16^{a}$ \\
\hline & G -2 & $0.57 \pm 0.09^{b}$ & $2.45 \pm 0.05^{b}$ \\
\hline & $G-3$ & $0.75 \pm 0.05^{b}$ & $2.27 \pm 0.15^{b}$ \\
\hline & $G-4$ & $0.69 \pm 0.11^{b}$ & $2.49 \pm 0.03^{b}$ \\
\hline & $G-5$ & $0.51 \pm 0.03^{b}$ & $2.43 \pm 0.08^{b}$ \\
\hline \multirow[t]{5}{*}{ 40th d.p.t. } & G -1 & $2.04 \pm 0.02^{a}$ & $1.74 \pm 0.14^{\mathrm{a}}$ \\
\hline & G -2 & $0.56 \pm 0.05^{b}$ & $2.41 \pm 0.05^{b}$ \\
\hline & $G-3$ & $1.59 \pm 0.09^{c}$ & $1.89 \pm 0.19^{c}$ \\
\hline & $G-4$ & $1.35 \pm 0.11^{c}$ & $1.99 \pm 0.02^{c}$ \\
\hline & $G-5$ & $2.11 \pm 0.03^{a}$ & $1.70 \pm 0.02^{a}$ \\
\hline \multirow[t]{5}{*}{ 60th d.p.t. } & G -1 & $2.03 \pm 0.02^{a}$ & $1.74 \pm 0.18^{a}$ \\
\hline & G -2 & $0.53 \pm 0.11^{b}$ & $3.25 \pm 0.05^{b}$ \\
\hline & $G-3$ & $1.12 \pm 0.06^{c}$ & $1.98 \pm 0.14^{c}$ \\
\hline & $G-4$ & $1.01 \pm 0.15^{c}$ & $2.88 \pm 0.06^{c}$ \\
\hline & $G-5$ & $2.01 \pm 0.10^{a}$ & $1.71 \pm 0.13^{a}$ \\
\hline
\end{tabular}


Fascioliasis is a worldwide parasitic disease that causes public health problems and losses in the infected ruminants' production. The infection with liver fluke adversely affects the general health conditions of the infected animals as weakness, liver damage and decrease in fertility (Kaplan 2001). Large varieties of flukicide drugs are available but excessive dependence on anti-parasitic drugs may cause resistance (Kelley et al. 2016). Moreover, treatment using flukicides did not induce fast improvement in the animal's condition due to the nature of damage that occurs in the liver cells due to the parasitic infection (Shrimali et al. 2016). For these reasons, supplying the infected animals with minerals and vitamins is important as they have important roles in improvement of animals' immunity and health condition and also they play a critical role in oxidative and energy metabolism in ruminants which are directly or indirectly involved in growth, production and reproduction (Kafilzadeh et al. 2014) and (Zoidis et al. 2018).

Therefore, the present study aimed to evaluate the synergistic effect of using Viteselen (as anti-oxidant) with TCBZ (as specific anti-Fasciola drugs) on effective eradication of Fasciola and improvement the body condition and productivity in group of sheep naturally infected with this parasite with reference to some hematological, biochemical and oxidative stress parameters in sera as measuring of these parameters could be useful in early diagnosis and prognosis of sheep fascioliasis and could be used to monitor the progress of infection (Hodzic et al. 2013 and Bahrami et al. 2014)

In the present study, the level of Fasciola infection was determined for all selected ewes via estimation of F. gigantica eggs but these eggs may be stored in the gall bladder and their shedding in feces was affected by the rate of bile flow and the presence of eggs in feces did not directly reflect an active infection. Moreover, false positive results may occur due to eggs' retention in the gall bladder for at least 2 weeks after successful treatment (El-Bahy et al. 2017). For these reasons and due to the importance of determination the direct relation between time of eradication of the parasite and improvement in the investigated parameters of the selected ewes, the present study depended also on determination the presence or absence of $F$. gigantica circulating antigen in sera as the presence of circulating parasite antigen in sera was directly related to presence of active infection (Taher et al. 2017).

The study proved that eradication of infection in the treated ewes was related directly to administration of TCBZ alone or in association with anti-oxidant. Both treatments causing sharp decrease in the mean number of e.p.g and the value of FCAg in sera of treated animals (G-3 and G-5) at 7th d.p.t while complete disappearance of eggs from feces of these infected treated animals was recorded at 21 st d.p.t. Moreover, the value of FCAg was decreased to negative at the 14th d.p.t in both groups. Addition of antioxidant reflected in improvement of the other parameters in association with the treatment action of TCBZ. High efficacy of TCBZ in complete eradication of Fasciola infection was previously described by several authors as it the only drug able to eradicate the early juvenile pre-mature fluke than other antiFasciola drugs (El-Bahy et al. 2009).

Concerning the hematological parameters (RBCs, $\mathrm{Hb}$ and TLC) in the present study, it was found that infected ewes showed significant mean reduction in RBCs and $\mathrm{Hb}$ than that in the non-infected group. 
This result is supported by Yesuf et al. (2020) who reported severe anemia in sheep infected with Fasciola. Moreover, the low mean values of total erythrocytes and $\mathrm{Hb}$ in the infected sheep might be due to hemorrhage which follows the severe damage caused by extensive migration of young fluke and blood sucking activity of the adult fluke (Radostits et al. 2007). Furthermore, the continuous drainage of iron stores and depression of erythropoiesis due to inflammation of liver could be responsible for reduction in total RBCs and related components (Chandra et al. 2011). The presence of leukocytosis in the infected ewes is supported by previous findings reported by Zhang et al. (2005) who stated that presence of leukocytosis in case of Fasciola infection may be due to marked eosinophilia which is associated with parasitic infection. The improvement of hematological parameters of the treated animals in the present study was in agreement with Soliman (2015) as the author mentioned that vitamin E and Se supplementation reduce the hemolysis of blood erythrocytes and enhance erythropoiesis.

Regarding to the level of liver enzymes (ALT and AST) in sera, it was revealed that there was an increase in the level of these enzymes in sera of the infected group in comparison to the healthy one. The same findings agreed with that reported by Pandya et al. (2015). This may refers to the toxic and mechanical effects of Fasciola spp on liver cells which leads to release of intracellular hepatic enzyme to the circulation that can increase their serum level (Hodzic et al. 2013 and Shrimali et al. 2016). Moreover, it was noticed that the investigated liver enzymes (AST and ALT) showing the same pattern of improvement which was recorded in the hematological parameters in the treated animals in comparison with the control group. This may be due to the effect of Se and Vit E which decreased the activities of AST and ALT to the normal level after treatment of animals from Fasciola as reported by Mehrdad (2011).

Concerning the values of oxidative stress and antioxidant markers, it was found that the concentration of (TAC, SOD and GSH) was significantly lower in the infected non treated group than that in the control non infected one. While the level of MDA increased in the infected non treated group. The highest significant improvement of these parameters was recorded at 60 th d.p.t. especially in $\mathrm{G}-5$ as the synergistic action of addition of TCBZ and Viteselen revealed non-significant differences in comparison with the healthy control group. This was in agreement with Alhidary et al. (2014) who reported that adding vitamin E and Se can increase serum TAC, SOD, GSH and decrease MDA to the normal levels. Deger et al. (2008) and Ahmed et al. (2020) stated that supplying the animal with antioxidants reduces the oxidative stress in tissues and prevents lipid oxidation. In addition, antioxidants have a cellular protective action that resulted from parasitic invasion, Moreover, Hamam and Abou-Zeina (2007) noticed that administration of Se and Vit E significantly improved the level of serum antioxidant markers of sheep.

There is a relation between Fasciola infection and decreasing the fertility of infected animals due to alternation of normal metabolism and balance of sex hormones (Kaplan 2001). Therefore, the present study determined the variations in values of some reproductive hormones (Progesterone and Estradiol) in the investigated sheep sera. Our study showed a significant increase in Estradiol in the Fasciola infected animals in comparison to the healthy group. The same results were reported by El-Khadrawy et al. (2008). It was revealed that improvement in all of previous investigated parameters reflected also on the 
estimated reproductive hormones in our study as it was found that $E_{2}$ concentrations decreased significantly while, P4 increased significantly in the treated groups in comparison to the control group. Mejia et al. (1999) and Lacau-Mengido et al. (2000) reported that anti-parasitic treatment caused an earlier onset of ovarian function following to the increased rate of growth.

Using of vitamins and trace minerals could enhance the animal immunity and improve its productivity and support cell division, differentiation and growth. Moreover, vitamins have a cellular protective action against oxidative stress that developed in damaged tissue due to the parasitic invasion (Soliman 2015). Therefore, combinations of antioxidants and flukicides drugs may be more effective than applying larger quantities of any single product of them (Young and Lowe 2001).

In the present study, the highest significant improvement $(\mathrm{p}<0.05)$ in the clinical parameters among different groups was recorded in (G-5) that treated by TCBZ and Viteselen, followed by animals in G-3 that treated by TCBZ only. While non-significant improvement in different parameters was recorded in animals in G-4 that received the anti-oxidant only, this was in comparison with infected non treated animals in G-2. The non-significant improvement in animals in G-4 was related to the presence of infection; as this group did not receive TCBZ treatment. In the author's opinion; anti-oxidant improves the general health conditions but it must associated by specific treatment that eradicate the present parasite. Therefore, the highest improvement in general health condition of the infected animals was achieved mainly by using a combination of specific treatment and the selected anti-oxidant as the condition recorded in G-5 in the present study. The specific drug succeeded in getting rid of the parasitic load in the animal, while the anti-oxidant improved its general health conditions. This was in agreement with Milad et al. (2001) as they reported that sheep supplemented with a combination of selenium and vitamin $E$ showed better improvement in immunological and organ function parameters. This effect was higher using a combination of these elements than supplementation with only one of the same element. It was worthy to mention that there is a direct relation between the recorded improvement of the estimated parameters in the present study and time elapsed post treatment in most cases; this was clear at 60th d.p.t. This was in agreement with Moeini and Jilani (2014) and Soliman (2015) who stated that the supporting action of anti-oxidant improves the immune response of the body and this increased with time post treatment.

\section{Conclusion}

Administration of Viteselen as a specific anti-oxidant in combination with Triclabendazol succeeded to improve the hematological and biochemical parameters, health condition and reproductive performance of the affected ewes in the present study.

\section{Declarations}

\section{Financial support}


This research received no specific grant from any funding agency, commercial or not-for-profit sectors.

\section{Conflict of interest}

The authors declare there is no conflict of interests.

\section{Ethical approval}

All study steps and procedures were performed according to the instructions stated by the Institutional Animal Care and Use ethical Committee (CU-IACUC) of Cairo University.

\section{References}

Ahmed AE, Alshehria A, Al-Kahtania MA, Elbehairia SI, Alshehria MA, Shatia AA, Alfaifia MY, Al-Doaisa AA, Taha R, Morsey K, El-Mansia AA (2020) Vitamin E and selenium administration synergistically mitigates ivermectin and doramectin-induced testicular dysfunction in male Wistar albino rats. Biomed Pharmacother 124. https://doi.org/10.1016/j.biopha.2020.109841

Abou-Zeina HAA, Hassan SG, Sabra HA, Hamam AM (2009) Trials for Elevating Adverse Effect of Heat Stress in Buffaloes with Emphasis on Metabolic Status and Fertility. Glob Vet 3: 51-62. http://www.idosi.org/gv/gv3(1)09/9.pdf

Alhidary IA, Shini S, Al-Jassim RAM, Abudabos AM, Gaughan JB (2014) Effects of selenium and vitamin E on performance, physiological response, and selenium balance in heat-stressed sheep. J Anim Sci 93:576-588. DOI: 10.2527/jas.2014-8419

Attallah AM, Ismail H, El Masry SA, Rizk H, Handousa A and El Bendary M, Tabll A, Ezzat F (1999) Rapid detection of a Schistosoma mansoni circulating antigen excreted in urine of infected individuals by using a Monoclonal Antibody. J Clin Microbiol 37: 354-357. DOI: 10.1128/JCM.37.2.354-357.1999

Bahrami S, Esmaeilzadeh S, Oryan A (2014) Role of oxidative stress in concomitant occurrence of Fasciola gigantica and leiomyoma in cattle. Vet Parasitol 203: 43-50. DOI: 10.1016/j.vetpar.2014.02.047

Bradford MM (1976) A Rapid and Sensitive Method for the quantitation of microgram quantities of protein utilizing the principle of protein-dye binding. Anal Biochem 72: 248-254.

https://doi.org/10.1006/abio.1976.9999

Chandra D, Singh K, Rathore R, Raina O, Varghese A (2011) Acute Fasciolosis in cattle and buffaloes in Bareilly district. Indian J Vet Pathol 35: 133-135. http://agris.fao.org/agris-search/search.do? recordID $=$ IN2012000072

Cortossa S, Aon MA, Waston RL, 'Rourke B (2004) A mitochondrial oscillator dependent on reactive oxygen species. Biopysic J 87: 2060-2073. DOI: 10.1529/biophysj.104.041749 
Deger Y, Ertekin A, Deger S, Mert H (2008) Lipid peroxidation and antioxidant potential of sheep liver infected naturally with distomatosis. Turkiye Parazitol Derg 32: 23-26.

\section{https://pubmed.ncbi.nlm.nih.gov/18351546/}

El-Bahy MM, El-Bahy NM, El-Shehawy SA (2009) A Model for strategic control of sheep parasites at Qassim Region, Saudi Arabia. Res J Parasitol 4: 33-44. DOI: 10.3923/jp.2009.33,44

El-Bahy MM, Geniedy MR, Meabed EMH, Bazh EKA (2017) Development of Fasciola gigantica Experimentally in Egyptian Rabbits. J Egypt Soc Parasitol 47: 709-716. DOI: 10.12816/JESP.2017.77735

El-Khadrawy HH, Faragalla M, El Moghazy, Abd El Aziz MM, Ahmed WM (2008) Field Investigation on the Correlation between Ovarian Activity and Fascioliosis in Buffalo-Cows. Am Euras J Agric Environ Sci 3: 539-546. http://www.idosi.org/aejaes/jaes3(4)/5

Feldman, Zinkl JG, Jain NC (2000) "Schalm's Vetrinary Hematology", $5^{\text {th }}$ ed., Lea and Febiger, Philadlphia, USA. https://doi.org/10.7589/0090-3558-36.2.393

Hamam AM, Abou-Zeina HAA (2007) Effect of Vitamin E and Selenium Supplements on the Antioxidant Markers and Immune Status in Sheep. J Biol Sci 6: 870-878. DOI: 10.3923/jbs.2007.870.878

Hodzic A, Zuko A, Avdic R, Alic A, Omeragic J, Jazic A (2013) Influence of Fasciola hepatica on serum biochemical parameters and vascular and biliary system of sheep liver. Iran J Parasitol 8: 92-98. https://www.ncbi.nlm.nih.gov/pmc/articles/PMC3655246/

Kaneko JJ, Harvey JW, Bruss ML (2009) Clinical Biochemistry of Domestic Animals, 6th Edition. https://doi.org/10.1111/j.1939-165X.2009.00202.x

Kafilzadeh F, Kheirmanesh H, Shabankareh HK, Targhibi MR, Maleki E, Ebrahimi M, Meng GY (2014) Comparing the effect of oral supplementation of Vitamin E, injective Vitamin E and selenium or both during late pregnancy on production and reproductive performance and immune function of dairy cows and calves. Sci World J 2014. http://dx.doi.org/10.1155/2014/165841

Kaplan RM (2001) Fasciola hepatica: a review of the economic impact in cattle and considerations for control. Vet Therapeut 2: 40-50. https://pubmed.ncbi.nlm.nih.gov/19753697/

Kelley JM, Elliott, Beddoe TP, Anderson T, Skuce GP, Spithill TW (2016) Current threat of triclabendazole resistance in Fasciolahepatica. Trends Parasitol 32: 458-469. https://doi.org/10.1016/j.pt.2016.03.002

Lacau-Mengido, IM, Mejía ME, Díaz-Torga G S, Gonzalez, IA, Formía N Libertun C, and Becú-Villalobos D (2000) Endocrine studies in ivermectin-treated heifers from birth to puberty. J Anim Sci 78: 817-824. https://doi.org/10.2527/2000.784817x

Langley RJ, Hillyer GV (1989) Detection of circulating parasite antigen in murine fascioliasis by two-ste enzyme-linked immunosorbent assays. Am J Trop Med Hyg 41: 472-478. 
Mahdy OA, Mousa WM, Abdel-Maogood SZ, Abdel-Radi S, El-Bahy MM (2017) Characterization of immunogenic protein fractions of sheep cysticercosis in Cairo, Egypt. J Hellenic Vet Med Soc 68: 291298. https://doi.org/10.12681/jhvms.15471

Marrero CAR, Santiago N, Hillyer GV (1988) Evaluation of immuno-diagnostic antigens in the excretorysecretory products of F. gigantica. J Parasit 74: 646-652. https://doi.org/10.2307/3282184

Mehrdad M, Abdollah E, Norouzian MA, Mohammad HB, Hesam AS (2011) Parenteral selenium and vitamin E supplementation to lambs: Hematology, serum biochemistry, performance and relationship with other trace Elements. Biol Trace Elem Res 139: 308-316. DOI: 10.1007/s12011-010-8659-4

Mejía M, Gonzalez-Iglesias A, Díaz-Torga GS, Villafañe P, Formía N, Libertun C, Becú-Villalobos D, LacauMengido IM (1999) Effects of continuous ivermectin treatment from birth to puberty on growth and reproduction in dairy heifers. J Anim Sci 77: 1329-1334. https://doi.org/10.2527/1999.7761329x

Milad K, Racz O, Sipulova A, Bajova V, Kovac G (2001) Effect of vitamin E and selenium on blood glutathione peroxidase activity and some immunological parameters in sheep. Vet Med 46: 1-5. DOI: 10.17221/7843-VETMED

Moeini MM, Jalilian MT (2014) Effect of Selenium and Vitamin E Injection during late pregnancy on immune system and productive performances of Sanjabi ewes and their lambs. Global J Anim Sci Res 2: 210-219. http://www.gjasr.com/.../141

Munro CJ, Stabenfeldt GH, Cragun JR, Addiego LA, Overstreet JW, Lasley BL (1991) Relationship of serum estradiol and progesterone concentrations to the excretion profiles of their major urinary metabolites as measured by enzyme immunoassay and radioimmunoassay. Clin Chem 37: 838-844. https://pubmed.ncbi.nIm.nih.gov/2049848/

Pandya SS, Hasnani JJ, Patel PV, Dave CJ, Ravi SN (2015) Study on haemato biochemical alterations occurred in Fasciola spp. infected Buffaloes. Int Multidiscip Res J 2: 756-759. Corpus ID: 90988718

Placer ZA, Cushman LL, Johnson BC (1966) Estimation of product of lipid peroxidation (malonyl dialdehyde) in biochemical systems. Anal Biochem 16: 359-364. DOl: 10.1016/0003-2697(6ㅡ) $\underline{90167-9}$

Radostits OM, Gay CC, Hinchcliff KW, Constable PD (2007) Veterinary medicine. A textbook of the diseases of cattle, sheep, pigs, goats and horses, 10th edn. Bailliere Tindall, London, pp 1576-1579. https://www.elsevier.com/books/veterinary-medicine/radostits/978-0-7020-2777-2

Rai S, Wahile A, Mukherjee K, Saha B, Mukherjee PK (2006) Antioxidant activity of Nelumbo nucifera [sacred lotus] seeds. J. Ethnopharmacol 104: 322-327. https://doi.org/10.1016/j.jep.2005.09.025 
Rinaldi1 L, Biggeri A, MusellaV, Waal T, Hertzberg H, Mavrot F, Torgerson PR, Selemetas N, Coll T, Bosco A, Grisotto L, Cringoli G, Catelan D (2015) Sheep and Fasciola hepatica in Europe: the GLOWORM experience. Geospat Health 9: 309-317. https://doi.org/10.4081/gh.2015.353

Shrimali RG, Patel MD, Patel RM (2016) Comparative efficacy of anthelmintics and their effects on hemato-biochemical changes in fasciolosis of goats of South Gujarat. Vet World 9: 524-529.

Doi: 10.14202/vetworld.2016.524-529

Soliman EB (2015) Dose- response of vitamin e and selenium injection on growth performance, physiological and immune responses of Ossimi lambs. EJSGS 10: 27-40.

DOI:10.21608/EJSGS.2015.26664

Soulsby EJ (1982) Helminthes, Arthropods and Protozoa of Domesticated Animals (Textbook): $6^{\text {th }}$ Edition, Bailliere Tindall \&Cassell, London. https://doi.org/10.1016/0035-9203(84)90110-X.

Taher EE, Meabed EMH, El Akkad DMH, Kamel NO, Sabry MA (2017) Modified dot-ELISA for diagnosis of human trichinellosis. Exp Parasitol 177: 40-46. https://doi.org/10.1016/j.exppara.2017.04.002

Welch S, Smith PH, Malone JB, Holmes RA, Geaghan JP (1987) Herd evaluation of Fasciola hepatica infection in Louisiana cattle by an ELISA. Am J Vet Res 48: 345- 347.

https://pubmed.ncbi.nlm.nih.gov/3565887/.

Yesuf M, Erara M, Kenubih A, Belay A, Ahmedin N (2020) Hemato-biochemical profiles of sheep infected with fasciolosis in comparison with health controls. Online J Anim Feed Res 10: 71-75. https://dx.doi.org/10.36380/scil.2020.ojafr10

Young AJ, Lowe GM (2001). Antioxidant and prooxidant properties of carotenoids. Arch Biochem Biophys 385: 20-27. https://doi.org/10.1006/abbi.2000.2149

Zhang WY, Moreau E, Hope JC, Howard CJ, Huang WY, Chauvin A (2005) Fasciola hepatica and Fasciola gigantica: comparison of cellular response to experimental infection in sheep. Exp Parasitol 111: 154159. https://doi.org/10.1016/j.exppara.2005.06.005

Zoidis E, Seremelis I, Kontopoulos N, Danezis GP (2018) Selenium-Dependent Antioxidant Enzymes: Actions and Properties of Selenoproteins. Antioxidants 7: 66. https://doi.org/10.3390/antiox7050066 